\title{
TAILORED RESEARCH: ON GETTING THE RIGHT FIT BETWEEN MACRO- LEVEL THEORY AND MICRO-LEVEL DATA
}

\author{
Mark T. Shutes \\ Department of Anthropology \\ Youngstown State University \\ Youngstown, $\mathrm{OH} 44555$ USA \\ FR191601@ysub.ysu.edu
}

Copyright 1996 by Mark T. Shutes.

\section{v. $7 / 8 / 96$}

\begin{abstract}
Ethnographers often criticize broad theoretical models, such as the one offered by General Systems Theory, as being insensitive to unique historical processes and events that can dramatically affect decision-making at the local level. Using data drawn from both a Greek and an Irish rural community, this work examines the validity of such criticism and concludes that there is no necessary inconsistency between variable -level theory and data, provided that the ethnography itself incorporates the appropriate kinds of data.
\end{abstract}

\section{Introduction}

The title of this paper reflects a continuing problem for ethnographic research: how can macro-level theories about social change help ethnographers to make broader comparative sense of the changes they observe and an alyze at the micro-level? How, in other words, can the ethnographer safely "study-up"? Using three factors that I have found to be useful in the local-level analysis of change, I will compare and contrast two European farming groups in order to show how World Systems Theory (WST) (1) can enrich our understanding of the changes that are taking place within these groups. Reciprocally, I wish also to demonstrate how local-level analysis of change, accomplished in the manner suggested, can enrich our understand ing of how macro-level changes in economy and hegemony of the sort suggested by WST are actually interpreted and modified at the local level.

[Page 1]

Joumal of World-Systems Research

\section{Local-Level Change \& World Systems Theory}

Before initiating this present work, I found myself skeptical of WST, not because of any fundamental objections, such as the novelty of the approach within anthropology or its 
basic inconsistency with existing anthropological theory and method, for there was ample literature linking WST with anthropology in those regards (cf. Hall and Chase-Dunn 1993, 1994; Nash 1981). Rather it was because such a broad-based historical theory covering thousands of years of world economic and political change seemed hardly able to contribute in any meaningful way to my further understanding of the micro-processes of change that were taking place in the Greek and Irish groups that I studied. Nor did the bulk of WST seem particularly interested in the kind of findings that my ethnographic data were generating. On both accounts, the scale of the events being described seemed entirely inappropriate, and the degree of complexity that was exhibited at the local level appeared to defy any kind of global general-process explanation. What I had failed to recognize was that, just as I had come to the point in my research where I was looking to "study-up," so certain WST theorists had begun to see the need to "study-down." Consider the following by Frank and Gills (1995):

...the world system approach must be extended by research into the cansality of the cycles, both the economic and the hegemonic, and their mutual relations. In this regard and even if they may not be causative, the intervention of climatic, ecological, and demographic change, and their relations with each other and in turn with social structural ones have received far less attention than they surely merit. This problematique also invites further research into how local conditions interact with systemic level impulses and stimuli. Specifically, there should also be further research into how local responses affect ascent and decline in the "inter-linked hegemonies" hierarchy (40).

In a similar vein, Hall and Jones (1995) state that:

What we need here is not an overthrow or revolution, but a chan ge in perspective. World-system analysts need to...study how system-wide processes and dynamics shape local processes and dynamics in transforming, sometimes transmuting, local class, raciallethnic, and gender relations. We need to devote special attention to how local actors attempt, and sometimes

[Page 2]

Journal of World-Systems Research

succeed, in resisting, or at least turning to their own advantage, various global forces (13).

In reading these calls for more local research, I realized that my low-level, pragmatic approach to understanding local social change, what I called production -oriented ethnography, had the potential to link more strongly their research goals with my own, and that what I had been doing at the local level was, in fact, a form of WST analysis. What follows is an exploratory attempt to demonstrate that linkage through the comparison of two European farming groups. 


\section{Production-Oriented Ethnography}

Elsewhere, I have stated that any reasonable analysis of the changes taking place within small farming populations should be based upon a data-collection approach that I have called production-oriented ethnography (Shutes 1994). The approach involves three factors that can be summarized as follows:

(1) It must incorporate a history of the various forms of capital accumulation introduced into the local rural community, and a careful documentation of the changes in production, and subsequent changes in social relations, that such introductions produced. Given the diverse and differentiated nature of this process, it is quite likely that any local group will exhibit a mixture of production strategies at any given point in time, governed by various forms of capital accumulation, and not simply exhibit a single "modern" or "peasant" strategy (cf. Breathnach and Cawley 1986; Curtin 1986; Curtin and Wilson 1989; Gibbon 1973; Goodman and Redclift 1982; Hannan 1982; Long et al. 1986; Mouzelis 1978; Popkin 1979; Shutes 1991,1993; Weintraub and Shapira 1975).

(2) The core of the historical analysis must be "strategic", that is, it must focus upon the active role that farmers play in making production decisions, and the economic, political and ecological factors that shape such decisions through time (Shutes 1994: 340).

(3) Finally, given the mix of production strategies, it is also likely that the existing social relations will reflect such a mix of strategies, an on-going "rules negotiation", if you

[Page 3]

Joumal of World-Systems Research

will. The approach must allow the investigator to identify the appropriate social rules that govern production decisions at any point in time, and the conditions under which such rules are "negotiable" (Ibid.: 341). These three factors were utilized in the comparisons that follow.

\section{Farm Group Comparison}

The groups in question are located at the geographic ends of the European Union (EU) in Southwestern Ireland and the Northern Peloponnesos in Greece, respectively. In many respects they are very much alike. Each shares a common set of market constraints and an emerging, though certainly not finalized, common polity within the EU. Their histories over the past one hundred years also reflect a common transition from mixed farming production, with a significant subsistence component (cows, cattle and roots crops for the Irish group and wheat, grapes and olives for the Greek group) to commodity production for the national and international marketplace. And, for each, that transition has been sporadic and unpredictable, as various forms of capital accumulation impacted upon local production plans. Farmers within each locale have had to adjust their production 
strategies to these new introductions and come to terms with the inevitable value conflicts and upheavals in social relationships that such adjustments entail. And certainly both groups belong to countries that are political and economic marginals within the EU itself.

But there are also some significant differences between the two populations that have resulted from this change to commodity production.

\section{(1) Monocropping Versus Multicropping}

The prevailing environmental conditions in Southwestern Ireland gave the farmers in the Irish group only a single option for the marketplace: milk production. This has resulted in the virtual abandonment of the other productive activities of their former mixed farming pattern in favor of dairying. The farmers of the Greek group, on the other hand, were forced to expand their inventory of mixed farming products to include a wide array of other fresh fruits and vegetables in order to accommodate the shift to commodity production for the marketplace.

(2) Disconnected Versus Connected Labor Orientation

[Page 4]

Journal of World-Systems Research

To be profitable, the Irish dairy farmers have had to eliminate hired or bartered labor, and depend solely upon the full-time labor of the farming family, supported by individuallyowned specialized dairying technology. The Irish farmers, therefore, whose former production strategy strongly tied households to each other in terms of labor dependency, have now become more disconnected and isolated. The Greek farmers, on the other hand, whose former strategy rewarded more disconnected and familistic behaviors, have had to increase their local labor dependencies in order to accommodate the increased variety of crop production that makes their commodity production profitable, and, hence are finding themselves more connected and interdependent at the local level.

\section{(3) Specialized Versus Generalized Capital Expenditure}

The Irish farmers must now invest heavily in specialized labor-saving dairying equipment in order to remain competitive, and cannot, at present, afford any change in strategy that would demand an increase in capital expenditure. The Greek farm households, in contrast, have had to be extremely flexible in their use of technology in order to be able to accommodate an increasing variety of crops, and so have not invested heavily in any one set of specialized production technologies.

(4) Underutilization Versus Overutilization of Land 
The move to specialized dairying for the Irish farmers has increased the competition among local producers for good grazing and silage land, but land which has no value for dairying remains underutilized. The farmers are, therefore, amenable to alternative uses of this land for tourist amenities, housing, and light industries, since they can gain through the sale of land to enterprises that do not compete with their dairying enterprises. The Greek farmers, on the other hand, need every available bit of land to accommodate their multiple commodity strategy, and find themselves, therefore in direct competition with other kinds of enterprises. Further, the pressure to overutilize existing land resources places a severe burden on the local ecology, particularly upon available water resources.

\section{(5) International Versus Local/Regional Markets}

As far as the farmers in the Irish group are concerned, the broad and highly regulated pricing system of the EU's international market best suits their ability to market their milk at

\section{[Page 5]}

Journal of World-Systems Research

a profit, since no local, regional or Ireland-wide market could ever sustain even the present productive capacity of dairying populations such as theirs. For the Greek farmers, the expanding local and regional markets for highly perishable fresh fruit and vegetables can often prove more profitable than bulk sales of such commodities via the EU. This is particularly true when the EU subsidizes certain varieties of produce that do not grow well under local conditions, or where the produce reflects local/regional tastes only. The farmers in the Greek group, therefore are wary of the highly regulated pricing systems and internationally standardized markets of the EU, and are more concerned about developing stronger local and regional markets for their produce.

\section{(6) Federation Versus Inter-Government Political Views}

As might be surmised from the above, the farmers in the Irish group more often favor continued political integration of the EU nations leading eventually to one federation of European states, since this will provide them with the kind of strong central control of the market that they find desirable. The Greek farmers, on the other hand, more often favor an extended period of economic integration with power remaining in the hands of individual member-states acting through inter-governmental councils. This approach is more consistent with their concerns that they have greater freedom to explore and exploit local and regional markets with less central control over their production decisions.

\section{Rules Negotiations}

Given the above information, it is possible to conceptualize the Irish farmers as moving away from a set of social rules that I have labeled Parochial towards one that I have 
labeled Cosmopolitan, whereas the farmers of the Greek group are moving in the opposite direction: from Cosmopolitan to Parochial social rules.

By Parochial rules I mean social constraints that lead individuals to define their role as a farmer/producer primarily in terms of local standards. Such standards are typically couched in terms of moral and ethical ideals concerning the manner in which a "good person" should behave towards fellow locals. Parochial rules tend to predominate in populations where farmers are strongly dependent upon each others' labor and assistance in order to accomplish

[Page 6]

Journal of World-Systems Research

their own production goals.

By Cosmopolitan rules I mean social constraints that lead individuals to define their role as a farmer/producer primarily in terms of external standards. These standards are typically couched in terms of the practical realities of being a "good farmer" and the need to insure the success of one's own enterprise. Cosmopolitan rules tend to predominate where no such labor dependency exists as a prerequisite for successful individual production.

When I say, therefore, that the Irish farmers are moving away from Parochial and towards Cosmopolitan rules, I mean the conditions are such that, when confronted with a decision about a change in production strategy, they will, whenever possible, choose a strategy that decreases their dependence upon other locals and justify their decision by reference to external standards for the "good farmer". Conversely for the Greek group, the conditions are such that, when farmers are confronted with a decision about a change in production strategy, they will, whenever possible, choose a strategy that enhances their interdependence with other group members and justify their decision by reference to local standards for the "good person".

Additionally, it is clear that, although one set of rules may predominate at any given point in time, the possibility for value conflict to disrupt the process of production decisions is always present. Some production decisions are governed by old standards and others by newer ones. Some are the result of creative compromise or invention, given a choice between difficult alternatives. In any event, an awareness of the factors that can influence a farmers' choices about what and how to produce can provide valuable insight into these potentially complex local-level processes. Two examples of farming decisions drawn from my fieldwork in Ireland and Greece, respectively, may prove useful at this juncture.

\section{Case \#1 Tomatoes Versus Oranges: Greece}


Two farmers, each of whom own small holdings totaling approximately fifteen stremata (slightly more than three acres), happen to have their single best fields of approximately one-half acre contiguous to each other. Their other holdings are scattered throughout the area and located on predominantly hilly and dry soil suitable only for olive cultivation. Each depends upon this larger field, therefore, as a source of stronger cash production, and each farmer had initially planted a variety of oranges that were subsidized by the European Union (EU) in order to minimize the risk. But the subsidized varieties did not

\section{[Page 7]}

Journal of World-Systems Research

grow well in Greece and demanded more and more investment in fertilizer and irrigation in order to maintain a stable crop production. Many orange growers with larger holdings had already shifted their production to other non-subsidized varieties of fruit and relied upon brokers to market their produce outside of the EU. This option was also available to these two farmers, but their production scale was so small that they could not risk the highly variable yearly price that they might receive from outside brokers.

Both fields are suitable for growing tomatoes, zucchini and other fresh produce for the burgeoning local markets in nearby towns and in Athens, some 60 miles to the northeast, but the yield from either field alone would not justify the cost of intensified and timely labor that such strategies demand. They decided to merge their two fields and to mutually share the labor and costs of vegetable and tomato production and marketing. They broke even during the first year of operation, but now earn more income from their combined activities than either would have earned from their separate production of the ill-growing subsidized oranges, and each is now more empowered in terms of their dealings with large and small food markets. Their families, however, who have inheritance rights in the fields, are worried about how this land can be fairly transmitted in the future, and there is always some grumbling about the amount of labor that one family invests versus the other. The farmers themselves, however, say that these are all things that will work themselves out, and that, after all, what can they do? They must look to more modern means to market crops or their families will have nothing to inherit at all.

\section{Case \#2 The Mechanical Calf-Feeder: Ireland}

A farmer with a large holding (110 acres) and eighty head of thoroughbred FresianHolstein milking cows was an active supporter of Ireland's entry into the EU in 1974, and has been instrumental in convincing many of his smaller farm neighbors to invest in more mechanized equipment and to specialize in milk production since that time. In the early 1980 s, he became convinced that the EU would soon impose quotas on milk-production, which would do severe harm to his small farm neighbors, since it had taken them more time and debt to upgrade the size of their herds just to their present levels, and any reduction in what they could sell to the market would place many of them into a situation of permanent debt. His own enterprise, because of its size and his early investment in 
equipment, was far less likely to suffer as markedly from such quotas, but he was greatly disturbed about the growing loss of control over their enterprises that he and his neighbors were suffering, and because he was, he felt, responsible for leading many of them in that direction. .

[Page 8]

Journal of World-Systems Research

Prior to entry into the EU, local farmers adjusted to lower income in dairy sales by keeping more of their calves for a year (one winter) and selling them to larger eastern farms for final fattening and sale as beef. Bad years in dairying would be balanced by sale of yearling cattle and bad years of cattle sales could be turned into higher milk production. Only when both failed at the same time, which was rare, would the loss be severe. But the bottom had fallen out of the world beef market since then, and calves now had to be sold right after birth and at markedly lower prices in order for farmers to maintain their capital investment in mechanized dairying.

The farmer in question here reasoned that if the local farmers could find a cheap way to feed the calves and enhance their weight gain in a shorter period of time, they might sell them as "pre-fattened" and gain a market with the eastern farmers again, and hence, some greater control over their production decisions. Artificial feeds of the sort used prior to the "bust" in the beef market were too expensive to be used for such fattening. The only other thing that produced significant weight-gain in calves in a very short time was milk "straight from the cow", but this method involved separating the dairy herd, was land and labor-intensive, and was unpredictable in terms of individual results.

If, however, he could develop a low-cost device that would supply a large number of calves a constant supply of whole, warm cows' milk, diverted from the creamery right after milking, then he could keep both enterprises separate and within minimal labor and land requirements. When the quota "crunch" came, therefore, as he was certain it would, farmers could initially divert the surplus part of their milk supply to the fattening of calves and, through the sale of those at increased weight, gain back their initial losses in milk production. And they could expand or contract either enterprise according to shifting market conditions. Control would be regained.

He spent three years of his own time and money developing the calf-feeding device. $\mathrm{He}$ acquired the part-time services of an underemployed engineer and an unemployed machinist, made them partners in the enterprise. When the device was perfected, he spent another year offering it to farmers from around the country on a free-trial basis in order to garner data about its effectiveness in producing short-term weight gain. To date, he has sold hundreds of the machines, many, at cost, to his own farm neighbors, and may have to go out of farming altogether just to manage the enterprise in the future. But when you ask him about this particular success, he will say that the best thing about all of it is that he again has the respect and admiration of his ne ighbors. 
[Page 9]

Journal of World-Systems Research

In both cases, there is clear evidence of the shifts from one set of rules to another in the manner in which I have suggested for each, although Case \#2 also indicates that reversal of such rules is also possible, since identification of the problem and the solution sought for it clearly indicate the strategy of a "good farmer," but at least part of the motivation for carrying out the invention of the calf-feeding device came from the stated desire to be viewed as a "good man" once again. Both decisions were motivated by a common set of external economic policies of the EU, but in neither case did the farmers behave in the manner in which the policy was designed.

\section{Discussion}

In light of the above, I believe that it is not unreasonable to suggest a strong "goodness of-fit" between my local-level, pragmatic approach to change and the broader claims of WST. Let me review briefly some of their shared aspects.

(1) Active Versus Passive -- My approach views individuals as active participants in their lives and production strategies. Crucial shared values, which give substance and meaning to farmer's decisions, are not viewed as monolithic determiners of production activity, but rather as the very stuff which is negotiated as various new kinds of capital accumulation infringe upon existing ones.

(2) System Interaction -- My approach views the members of farming groups as participants in a continuous series of political and economic systems that regularly challenge their existing notions of shared meaning, and that there has never been a time over the past few hundred years (the limits of my study) where this has not been the case. There have been periods where options for new forms of capital accumulation have been severely restricted, but this cannot be interpreted as evidence for the existence of some timeless period of "pre-modern" peasantry where only one form of production was possible.

(3) Inter-Linked Hegemonies -- Both the Greek and the Irish groups herein discussed share a very similar set of historical experiences. Both have moved in a relatively short time from colonial dominance by a foreign power/powers, through a late-developing nationalism, and into a multi-state political and economic union. Each of these experiences has introduced significant changes in production and concomitant social change within both groups, and,

[Page 10]

Journal of World-Systems Research 
although this may be stating the obvious, changes in the balance of world hegemony can be readily referenced to explain each of these periods in their histories.

(4) Hegemonic Transitions -- The introduction of new forms of capital accumulation into the two local farming groups has not been met by simple acceptance or rejection, regardless of the source of these new forms. Rather, they are evaluated in terms of local advantage and benefit and modified according to locally-negotiated social rules. The actual intent of the policy introduced by some larger hegemonic entity, therefore, is almost never realized as planned, for although the majority of the local groups may eventually incorporate the new strategy/strategies in some fashion, they will always keep their options open.

Nowhere is this "policy frustration" more clear than in an examination of the changes that have resulted from both groups' participation within the EU. As we have seen, a common agricultural policy has produced diametrically opposed political and economic views of the policy (and the EU itself) at the local level, and any change in existing policy, minor or major, could result in further changes in direction and views by either or both groups. Nor do I believe that it is accidental that these kinds of "local interpretations" are so strongly prevalent within two groups which are both on the periphery of the EU hegemony and marginalized players in the overall agricultural plan. It would seem obvious that, by their very position, such groups can eventually make or break an hegemony, as they pursue their own interests on the boundaries of competing hegemonic interests, and may even, at certain times, produce such power structures themselves, given their keen abilities to successfully negotiate various forms of capital accumulation. The implications of these local processes cannot be lost upon world system theorists and their concern for the ascent and decline of competing and inter-linked hegemonies. Indeed, this may be the most important role that such local-level ethnographic studies can perform within the framework of WST.

\section{Conclusion}

This paper has attempted to demonstrate that their exists a very good fit between a model for rural social change that I developed out of immediate and practical concerns for understanding the strategies of rural producers in two locations and WST. It is frequently the case that those who exhibit an acute interest in ethnography are often chary about the use of broad-based theories to explain the incredible richness and diversity of the human behavior

[Page 11]

Journal of World-Systems Research

that they encounter in their work. No such theory seems capable of doing explanatory justice to the complexities that they observe locally, and they are far more comfortable with the kind of low-level, pragmatic explanations that hover only slightly above the 
actual decisions made by locals in carrying out their productive lives. This has been the case for my work on rural decision-making. The value of WST, as I have discovered in this particular project, is that all of my ethnographic objections to it are met and incorporated. Not only can I retain my observation-based convictions that human beings everywhere are dynamic and active participants in the changing world that they encounter, but I can also safely "study-up" within the framework of a general theory that seems to embrace a similar set of methodological assumptions and theoretical convictions, and that also recognizes its own need to "study-down." Certainly there are other aspects of local life that play a role in these processes besides production, such as gender, ethnicity, migration, and the introduction of new kinds of consumer goods, but as long as they share a common flexible set of methodological and theoretical assumptions of the sort I have identified for production decisions, both ethnographic analysis and WST will only benefit through their mutual association.

\section{References Cited}

Breathnach, P., and M. Cawley (editors)

1986 Change and Development in Rural Ireland. Geographical Society of Ireland Special

Publications No. 1. Cardinal Press, Maynooth, Ireland.

Chase-Dunn, C., and T. D. Hall (editors)

1991 Core/Periphery Relations in Pre-Capitalist Worlds. Westview Press, Boulder.

[Page 12]

Journal of World-Systems Research

Chase-Dunn, C., and T. D. Hall

1992 World-Systems and Modes of Production: Toward the Comparative Study of

Transformations. Humboldt Journal of Social Relations 18(1): 81-117.

1993 Comparing World-Systems: Concepts and Working Hypotheses. Social Forces $71(4): 851-886$.

1994 The Historical Evolution of World Systems. Sociological Inquiry 64(3): 257-280.

Curtin, C.

1986 The Peasant Family Farm and Commoditization in the West of Ireland. In The 
Commoditization Debate: Strategy and Social Network, edited by N. Long, J. Douwe van der Ploeg, C. Curtin, and L. Box, pp. 58-76. Papers of the Department of Sociology No. 17. Agricultural University of Wageningen, The Netherlands.

Curtin, C., and T. M. Wilson (editors)

1989 Ireland From Below: Social Change and Local Communities. Galway University Press, Galway, Ireland.

Frank, A. G. and B. K. Gills (editors)

1993 The World System: Five Hundred Years or Five Thousand? Routledge, London.

Frank, A. G. and B. K. Gills

[Page 13]

Journal of World-Systems Research

1992 The Five Thousand Year World System: an Interdiscip linary Introduction.

Humboldt Journal of Social Relations: 18 (1): 1-79.

1995 The Five Thousand Year World System in Theory and Praxis. Paper presented at the 94th Annual Meetings of the American Anthropological Association, November 15 19, Washington, DC.

Goodman, D., and M. Redclift

1982 From Peasant to Proletarian: Capitalist Development and Agrarian Transitions. St.Martin's Press, New York.

Hall, T. D., and C. Chase-Dunn

1993 The World-Systems Perspective and Archaeology: Forward into the Past. Journal of Archaeological Research 1(2): 121-143.

1994 Forward into the Past: World-Systems Before 1500. Sociological Forum 9(2): 295 306.

Hall, T. D., and L. M. Jones

1995 New Developments in World-Systems Theory: Challenges for the Social Sciences. Paper presented at the Plenary Session of the International Studies Association, Midwest, Indianapolis, IN. 
Kardulias, P. N. (editor)

1994 Beyond the Site: Regional Studies in the Aegean Area. University Press of America, Lanham, MD.

[Page 14]

Journal of World-Systems Research

Long, N., J. D.van der Ploeg, C. Curtin, and L. Box (editors)

1986 The Commoditization Debate: Strategy and Social Network. Papers of the Department of Sociology No. 17. Agricultural University of Wageningen, The Netherlands.

Mouzelis, N. P.

1978 Modern Greece: Facets of Underdevelopment. Holmes and Meier, New York.

Nash, J.

1981 Ethnographic Aspects of the World Capitalist System. Annual Review of Anthropology 10: 393-423.

Popkin, S. L.

1979 The Rational Peasant: the Political Economy of Rural Society in Vietnam. University of California Press, Berkeley.

Shutes, M. T.

1991 Kerry Farmers and the European Community: Capital Transitions in a Rural Irish Parish. Irish Journal of Sociology 1: 1-17.

1993 Rural Communities Without Family Farms? Family Dairy Farming in the Post-1993 EC. In Cultural Change and the New Europe: Perspectives on the European Community, edited by T.M.Wilson and M.E.Smith, pp. 123-142. Westview Press, Boulder.

1994 Production-Oriented Ethnography: the Cultural Anthropologist's Role in Understanding Long-Term Social Change. In Beyond the Site: Regional Studies in the Aegean Area, edited by P. N. Kardulias, pp. 337-351. University Press of America,

[Page 15]

Journal of World-Systems Research 
Lanham, MD.

Wallerstein, I.

1974 The Modern World-System: Capitalist Agriculture and the Origins of European World-Economy in the Sixteenth Century. Academic Press, New York.

1980 The Modern World-System II: Mercantilism and the Consolidation of the European World-Economy, 1600-1750. Academic Press, New York.

1984 The Politics of the World-Economy: the States, the Movements, and the Civilizations. Cambridge University Press, Cambridge.

1989 The Modern World-System III: the Second Era of Great Expansion of the Capitalist World-Economy, 1730-1840s. Academic Press, New York.

1991 Geopolitics and Geoculture: Essays on the Changing World-System. Cambridge University Press, Cambridge.

Weintraub, D. and M. Shapira

1975 Rural Reconstmiction in Greece: Differential Social Achievements During the Development Process. Sage Publications, London.

Wilson, T. M., and M. E. Smith (editors)

1993 Cultural Change and the New Europe: Perspectives on the European Community. Westview Press, Boulder.

[Page 16]

Journal of World-Systems Research

\section{Note}

(1) This present inquiry is based upon the writings of Chase-Dunn and Hall (1991, 1992 , $1993,1994)$, that of Frank and Gills $(1992,1993,1995)$, Hall and Chase-Dunn $(1993,1994)$, and of Wallerstein $(1974,1980,1984,1989,1991)$, and accepts as valid the criticism offered by Frank and Gills (1995) and Hall and Jones (1995) that Wallerstein's version of World System Theory is, perhaps, too narrowly conceived and Euro-centric in orientation. World system research is, of course, a rapidly expanding and dynamic area, and the references cited above are only given as a general guide to the approach taken in 
this particular work. For a complete review of the relevant world system literature, see Hall and Jones (1995).

[Page 17]

Journal of World-Systems Research 